\title{
Congregations of wintering Egyptian Vultures Neophron percnopterus in Afar, Ethiopia: present status and implications for conservation
}

\author{
Volen Arkumarev ${ }^{1}$, Vladimir Dobrev ${ }^{1}$, Yilma D Abebe $^{2}$, Georgi Popgeorgiev ${ }^{1}$ and Stoyan C Nikolov ${ }^{1}$ \\ ${ }^{1}$ Bulgarian Society for Protection of Birds/BirdLife Bulgaria, Sofia, Bulgaria \\ 2 Ethiopian Wildlife and Natural History Society, Addis Ababa, Ethiopia \\ * Corresponding author, e-mail: volen.arkumarev@gmail.com
}

\begin{abstract}
The Endangered Egyptian Vulture Neophron percnopterus congregates in communal roosts in the wintering areas and where food availability is high, where even a single threat might lead to substantial population declines. Thus, more research on the congregation sites is needed for timely detection of threats and effectively directed conservation measures. We studied bird numbers, use of roosting substrates and roosting habitat of wintering Egyptian Vultures in Ethiopia. Vultures were counted using the road-count technique in 2009, 2010 and 2013 along c. $600 \mathrm{~km}$ of roads in the Afar region. Over 1000 individuals were counted each year and the sites with the highest congregations were identified. Nearly half of the birds were adults and the majority roosted on bird-safe types of electric pylons. Most of the Egyptian Vultures were found below $500 \mathrm{~m}$ above sea level, in bare areas, open savannas or grasslands, and their abundance was negatively related to the amount of cover of bush vegetation. The distribution of roosting birds was not affected by distance to human settlements. To avoid disasterous effects on the population of the Egyptian Vultures, we strongly recommend that the sites sheltering the highest numbers of roosting birds should be included in the Important Bird Area network, the use of poisons should be banned, and dangerous power lines should be insulated or substituted with safer types.
\end{abstract}

Keywords: Africa, declining population, endangered species, roosting, scavenger

\section{Introduction}

The Egyptian Vulture Neophron percnopterus is a mediumsized scavenger, distributed throughout southern Europe, northern and central Africa, the Middle East, Transcaucasia, Central Asia and the Indian subcontinent (FergusonLees and Christie 2001). Because of consistent and steep declines throughout its range, the species was up-listed from Least Concern to Endangered in the IUCN Red List in 2007 (Birdlife International 2008) with the global population estimated at 20 000-61 000 individuals (Birdlife International 2014a).

The Egyptian Vulture is a long-distant migrant in the northern part of its range. Up to 10000 Egyptian Vultures from Europe, Western and Central Asia enter Africa every autumn at four straits - Gibraltar, Sicily, Suez and Bab el Mandeb (Mundy et al. 1992). These Palaearctic migrants winter predominantly in the Sahel zone (Thiollay 1989; Mundy et al. 1992). Through satellite telemetry, Egyptian Vultures from Spain and France have been found to winter in Mauritania (Meyburg et al. 2004; Garcia-Ripollés et al. 2010), Italian individuals winter in central-east Mali (Ceccolini et al. 2009) and the wintering grounds of the Balkan population are mainly in Chad and Sudan, and occasionally in Niger, Nigeria, Ethiopia and Yemen (Meyburg et al. 2004; BSPB 2013). Wintering Egyptian Vultures can form large congregations as known in Chad (Salvan 1967), Sudan (Meinertzhagen 1954) and in the Afar region in Ethiopia (Levy and Mendelsohn 1989; Sigismondi and Politano 1996; Ash and Atkins 2009). Large congregations of wintering
Egyptian Vultures were reported to roost on telegraph pylons in December 1958 in a vast area between Dire Dawa in Ethiopia and the border of Djibouti (Levy and Mendelsohn 1989). Thirty-six years later a total of 1473 Egyptian Vultures roosting on $75 \mathrm{~km}$ of power lines were counted in the Afar region, Ethiopia (Sigismondi and Politano 1996). Although no data exist about where the Egyptian Vultures wintering in Ethiopia come from, there is evidence that some of these birds come from Asia (Ash 1981), eastern Turkey (Buechley and Sekercioglu 2013), south-eastern Europe (BSPB 2013) and possibly the Indian subcontinent (Angelov et al. 2013). Furthermore, little is known on roosting substrates and habitat use of the species in its wintering grounds in the Sahel zone (but see Sigismondi and Politano 1996; Meyburg et al. 2004; Wacher et al. 2013).

Egyptian Vultures wintering in the Sahel are exposed to a wide range of threats: electrocution (Angelov et al. 2012), unintentional poisoning during predator control and use of pesticides, degradation of habitat, reduced availability of carcasses due to decrease in wild animal numbers and changes in livestock breeding combined with improved management of carcass disposal, direct persecution and acquisition of vulture parts for traditional medicine and fetish market (Wilson 1982; Nikolaus 2001; Rondeau and Thiollay 2004; Thiollay 2007; Ogada et al. 2012; Wacher et al. 2013). If these threats operate in areas where vultures congregate in large numbers on migration or during wintering, losses could result in population-level 
consequences for the species (Angelov et al. 2012). Therefore, profound and consistent research is needed for the congregation sites in order to detect timeously potential threats and effectively direct conservation measures.

We present data on the recent numbers, roosting substrates and roosting habitat use of Egyptian Vultures wintering in the Afar region, to serve as a baseline for future monitoring, as well as to give insight on the potential threats and conservation priorities for the species.

\section{Material and methods}

\section{Study area}

The Afar region is located in the eastern lowlands of Ethiopia and shares its eastern border with Eritrea and Djibouti. Most of the Afar region is below $1000 \mathrm{~m}$ above sea level (asl) and the climate is very warm and arid, with a mean annual temperature of $35^{\circ} \mathrm{C}$ and midday temperatures of over $45^{\circ} \mathrm{C}$ (EWNHS 1996). Rainfall is sparse and irregular - less than $200 \mathrm{~mm} \mathrm{y}^{-1}$ over most of the north of the region, rising to about $500 \mathrm{~mm} \mathrm{y}^{-1}$ in the south. Ethiopia is believed to have the largest livestock population in Africa with more than 4380000 cattle, goats, sheep and draught animals raised in only two out of five administrative zones of the Afar region - Zones 1 and 3 (CSA 2013), where the study transects were located.

There are five protected areas (Yangudi-Rassa National Park, Awash West, Gewani and Mille-Sardo Wildlife Sanctuaries and Reserves, and Afdem-Gewani Controlled Hunting Area) and four Important Bird Areas (IBAs; Lake Abe Wetland complex, Aliyu Amba-Dulecha, Awash Rivere Valley and Yangudi-Rassa National Park) in the region. Regarding land use, modern agriculture has expanded rapidly since the 1970s through the use of agrochemicals, particularly fertilisers and pesticides (EWNHS 1996).

\section{Data collection}

This survey was conducted in December 2009 and 2010, and in January 2013 using the road-count technique (Thiollay 2006). The route was c. $600 \mathrm{~km}$ long and followed the roads along the main power lines in the Afar region. The observation points $(n=130)$ were located at an average distance of c. $5 \mathrm{~km}$ in areas with good visibility on the pylons, between 355 and $1480 \mathrm{~m}$ asl. We counted all roosting Egyptian Vultures in a single direction along the main road from Addis Ababa to the border with Djibouti - from $10 \mathrm{~km}$ east of Nazret (Adama) to Serdo and three additional routes: (1) Awash to $15 \mathrm{~km}$ on the Dire Dawa road, (2) $30 \mathrm{~km}$ east of Bati to Mile, and (3) Semera to $10 \mathrm{~km}$ east of Asaita (Figure 1). Double counts of the same individuals were avoided by recording the unique codes of the first and last mapped pylons on each observation point. All Egyptian Vultures were aged following Clark and Schmitt (1998): vultures in first plumage were considered as juveniles, second and third plumages as immature, fourth and fifth plumages as subadult, and adult plumage. Data were collected under suitable weather conditions for adequate visibility - no fog, heavy rain, etc., from 15:30 local time until darkness, by experienced observers.

All visible roosting substrates within a $2 \mathrm{~km}$ radius around observation points were investigated for roosting

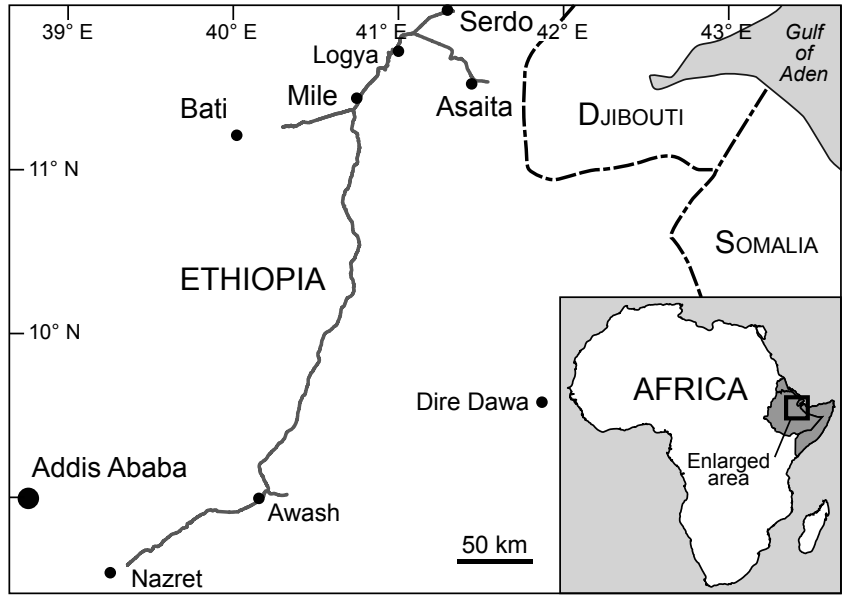

Figure 1: Map of the study area and road-transects in the Afar region, Ethiopia

vultures. We classified the powerline pylons based on their design (i.e. types of insulators, crossarm configuration and distance between wires) following Janss and Ferrer (2001) and Manosa (2001): (1) dangerous type, including low-voltage T-shaped pylons, low voltage $\Pi$-shaped pylons and low-voltage I-shaped pylons (Figure 2a) and (2) safe type, including high-voltage A-shaped pylons, communication towers, and pylons without wires (Figure 2b).

\section{Data analysis}

Analysis on the use of roosting sites and roosting habitats was based on a total of 4643 power pylons and communication towers mapped in 2013. For land-cover analysis we used study plots by applying a $2 \mathrm{~km}$ buffer around the observation points based on the GlobCover data (Bontemps et al. 2011) using ArcGIS 10.1 software (ESRI, Redlands, CA, USA, 2012). The analysis for the distribution of roosting vultures in relation to the disctance to the settlements was conducted based on three intervals: 0-6 km, 6-12 km and $>12 \mathrm{~km}$. Non-parametric tests were applied for statistical analyses because data were not normally distributed and did not approach the normal distribution even after transformation. Statistical comparisons and correlations were computed in STATISTICA 7.0 (StatSoft, Inc., Tulsa, OK, USA, 2004). Means are reported \pm one SE.

\section{Results}

\section{Vulture numbers, age ratio and roosting sites}

A total of 1424 wintering Egyptian Vultures were counted roosting in Afar region in 2009, 1400 individuals in 2010, and 1082 individuals in 2013. The age of $90 \%$ of the birds was identified. Adults represented $51 \%$ of counted individuals, subadults $7 \%$, and immatures and juveniles $32 \%$. The biggest congregations of c. 900 individuals in all three years (over $70 \%$ of the counted vultures) were found along the main road from Bati towards the border with Djibouti around the towns of Mile, Logya and Serdo. The majority of Egyptian Vultures (96\%) were roosting on safe types of pylons $\left(\chi^{2}=3944, \mathrm{df}=1, p<0.0001\right)$. There were no Egyptian Vultures found to roost on other substrates. 

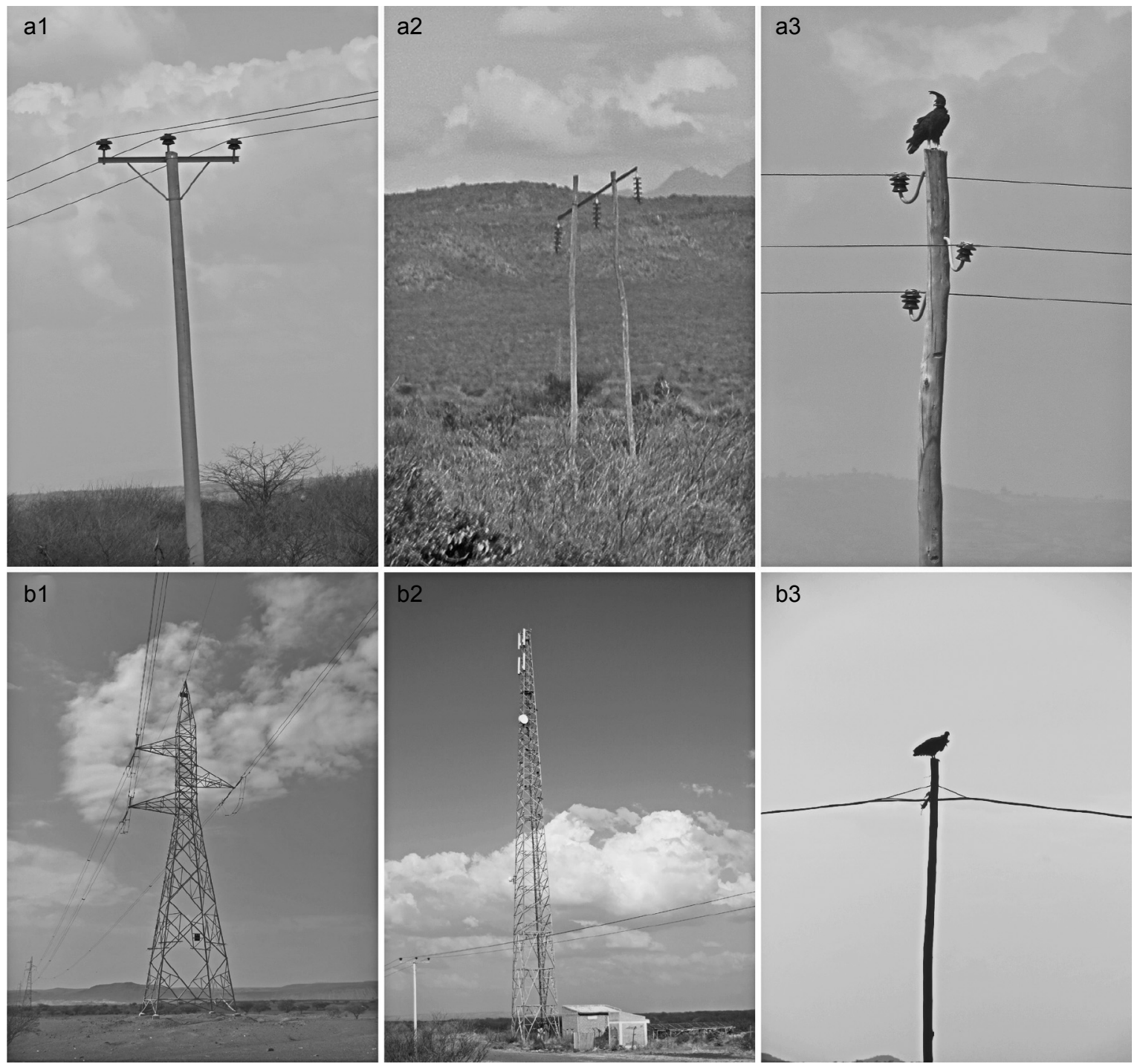

Figure 2: Types of power pylons as roosting substrates for Egyptian Vultures in the Afar region, Ethiopia. (a) Dangerous types, including (a1) low-voltage T-shaped pylon, (a2) low-voltage ח-shaped pylon and (a3) low-voltage I-shaped pylon; (b) safe types, including (b1) high-voltage A-shaped pylon, (b2) communication tower and (b3) pylon without wires

\section{Habitat use}

Most of the Egyptian Vultures (73\%) were roosting below $500 \mathrm{~m}$ asl and very few $(7 \%)$ at an altitude higher than $1000 \mathrm{~m}$ (Kruskal-Wallis test: $\left.H_{2,130}=37.18, p<0.00001\right)$. The birds showed an aggregated roosting distribution (mean $=8.32 \pm 1.33$ vultures per observation point, variance $=$ 231.91). There were slightly more roosting Egyptian Vultures within $6 \mathrm{~km}$ from the settlements (mean = 10.0 \pm 2.36 vultures per observation point) compared to those roosting at distance $6-12 \mathrm{~km}$ (mean $=7.02 \pm 2.26$ vultures per observation point) and over $12 \mathrm{~km}$ (mean $=7.91 \pm 2.34$ vultures per observation point). However, the roosting distribution of the species was not related to the distance to the settlements (Kruskal-Wallis test: $H_{2,130}=1.69, p=0.43$ ). Most of the observed Egyptian Vultures were roosting in bare areas, open savannas or grasslands, while the number of roosting Egyptian vultures was negatively related to the cover of mosaic forest or shrubland (bush) vegetation (Table 1).

\section{Discussion}

\section{Trends of roosting Egyptian vultures}

The present study confirms that the Afar region in Ethiopia is sheltering the most significant known wintering congregation of Egyptian Vultures in eastern Africa (Levy and Mendelsohn 1989; Sigismondi and Politano 1996; Ash and Atkins 2009), holding c. $3 \%$ of the global population of the species (BirdLife International 2014a). Significant congregations of the species (about 200) have been reported for Sudan (Meinertzhagen 1954), Oman (Al Balushi et al. 2013), and Chad (Salvan 1967), but the numbers of roosting vultures were lower compared to the Afar region. Congregations of similar magnitude to that of the Afar region so far have been reported only for India - 1171 individuals in the region of Rajasthan in 2004 (Chhanagani 2009). Moreover, it should be considered that our results are an underestimation of the real numbers of Egyptian 
Table 1: Spearman rank correlation between habitat cover and numbers of Egyptian Vultures per observation plot ( $N=130$ plots) in the Afar region, Ethiopia

\begin{tabular}{|c|c|}
\hline Habitat type & rho \\
\hline Rainfed croplands & $-0.22^{*}$ \\
\hline $\begin{array}{l}\text { Mosaic cropland (50-70\%)/vegetation (grassland/ } \\
\text { shrubland/forest) }(20-50 \%)\end{array}$ & $-0.26^{*}$ \\
\hline $\begin{array}{l}\text { Mosaic vegetation (grassland/shrubland/forest) } \\
(50-70 \%) / \text { cropland }(20-50 \%)\end{array}$ & $-0.31^{*}$ \\
\hline $\begin{array}{l}\text { Open (15-40\%) broadleaved deciduous forest/ } \\
\text { woodland }>5 \mathrm{~m} \text { ) }\end{array}$ & -0.14 \\
\hline $\begin{array}{l}\text { Mosaic forest or shrubland }(50-70 \%) / \text { grassland } \\
(20-50 \%)\end{array}$ & $-0.52^{*}$ \\
\hline $\begin{array}{l}\text { Closed to open }(>15 \%) \text { (broadleaved or needleleaved, } \\
\text { evergreen or deciduous) shrubland }(<5 \mathrm{~m})\end{array}$ & $-0.31^{*}$ \\
\hline $\begin{array}{l}\text { Closed to open }(>15 \%) \text { herbaceous vegetation } \\
\text { (grassland, savannas or lichens/mosses) }\end{array}$ & $0.37^{*}$ \\
\hline Sparse $(<15 \%)$ vegetation & $0.17^{*}$ \\
\hline $\begin{array}{l}\text { Closed to open }(>15 \%) \text { grassland or woody vegetation } \\
\text { on regularly flooded or waterlogged soil - fresh, } \\
\text { brackish or saline water }\end{array}$ & -0.17 \\
\hline Bare areas & $0.5^{*}$ \\
\hline
\end{tabular}

Vultures wintering in Afar region. Satellite-tracked immature individuals from Bulgaria, which overwintered in Afar in 2013 , spent most of the time in remote areas more than $20 \mathrm{~km}$ from the transects of the present study - in the rocky area south-west from Lake Abbe and vast savannas west of the Awash-Mile main road (BSPB 2013). These sites may hold significant numbers of Egyptian Vultures roosting on cliffs and trees that we have not counted.

One of the factors determining the formation of the wintering congregations of Egyptian Vultures in the Afar region could be the ability to achieve high foraging efficiency (Beauchamp 1999). The species is known to congregate in communal roosts in areas where food availability is high (Donázar et al. 1996) and such congregations have been reported from the whole range of the species (Brown and Amadon 1968, Cramp and Simmons 1980). Potential food for the Egyptian Vultures and other scavengers in the Afar region (Administrative Zones 1 and 3) are more than 470000 animals that die annually due to diseases or other reasons and 127000 more that are slaughtered (CSA 2013). Land degradation and overgrazing, which are widely increasing in the Afar region (Sonneveld et al. 2010), may also contribute to the high mortality rates of the livestock in the area.

The present study shows relatively lower number of wintering Egyptian Vultures (c. 300 individuals less) in the Afar region in 2013 compared with 2009 and 2010. The difference is a result mainly of lower numbers of recorded Egyptian Vultures along the transect between Nazret and Awash. This might be explained by the shorter transect length (18 km less), different time period and some local movements of the wintering vultures (the survey in 2013 was conducted in January, whereas those in 2009 and 2010 were in December). However, this might also be a signal for a decline in the source populations. In general, a comparison of the data for wintering Egyptian Vultures in the Afar region collected after 2000 with information from the 1990s a total of 1473 individuals counted for only $75 \mathrm{~km}$ of power lines; Sigismondi and Politano (1996) suggests declines in the numbers of wintering Egyptian Vultures in the area over the last 15 years.

\section{Roosting substrates}

We found that Egyptian Vultures in the study area roost only on powerline pylons and communication towers, in accordance with what was previously reported for the area (Sigismondi and Politano 1996). Powerline and telegraph pylons are 'traditionally' used for roosting also in other parts of the wintering grounds, e.g. in Port Sudan (Meinertzhagen 1954; Angelov et al. 2012). However, it is known that at congregation sites the species uses other substrates for roosting as well. Communal roosts on trees are reported from Istanbul (Turkey), Macaronesian islands (Cramp and Simmons 1980), Egypt (Goodman and Atta 1987), Socotra (Porter and Suleiman 2012) and Spain (Ceballos and Donázar 1990, Donázar et al. 1996, Margalida and Boudet 2003), where Egyptian Vultures mainly use large dead trees (Ceballos and Donázar 1990). Less often, roosting may be on cliffs in Menorca, Spain and Socotra (Congost and Muntaner 1974; Donázar et al. 1996; Porter and Suleiman 2012) or even on the ground in Sudan (Meinertzhagen 1954).

In many treeless areas where availability of perches and roosts may limit raptor populations, electrical powerline structures are readily utilised by many raptor species (Stahlecker 1979; Olendorf et al. 1981). In the middle of the twentieth century, Meinertzhagen (1954) reported a large concentration of Egyptian Vultures near Port Sudan, with roosts of 200 birds on telegraph pylons and 'many more' roosting on the ground. Levy and Mendelsohn (1989) reported another large congregation of the species seen in 1958 roosting on telegraph pylons in Afar. These records show that, in the absence of suitable trees or cliffs, in areas with high food abundance Egyptian Vultures may roost even on the ground or use different artificial structures. With infrastructural development and electrification of African countries, more powerlines have been built and recent surveys proved that Egyptian Vultures are often utilising powerline pylons as roosting substrates (Sigismondi and Politano 1996; Angelov et al. 2012). We found that the majority of Egyptian Vultures were roosting on high-voltage powerline pylons and communication towers, which are the highest artificial structures in the area. This is in agreement with the known fundamental factors determining the selection criteria for roosting substrate - the size of the substrate (to support more birds at a time) and easy access (Ceballos and Donázar 1990). We speculate that roosting high above the ground in densely populated areas seems to be beneficial for the vultures also in terms of safety and is expected to be related with lower disturbance rates (Beauchamp 1999).

\section{Habitat use}

Most of the Egyptian Vultures in the study area were roosting in bare areas, open savanna and grasslands below $500 \mathrm{~m}$ asl. Similar habitat use has been observed for Egyptian Vultures wintering in Mauritania and Chad 
(Meyburg et al. 2004). Afar is a depression and represents an open lowland (EWNHS 1996), which supports large livestock populations characterised by high annual death rates $(10.7 \%)$ (CSA 2013), thus ensuring high availlability of food for scavengers. Due to the shrinking area of grazing lands and water shortages in these dry open habitats, livestock are forced to trek further in order to find feeding grounds and sufficient water supplies (UN-EUE 2002; Ilyin 2011). Therefore, animals are using a significant portion of their energy for basic maintenance (Ilyin 2011). Prey mortality may be a more important driver of vulture habitat use than prey abundance and in the Mara-Serengeti ecosystem different vulture species show greater use of migratory herds of wild ungulates during the dry season, when migratory-herd mortality is high (Kendall et al. 2013). The production system of the Afar region is dominated by pastoralism. Pastoralists in Afar raise goats, sheep and cattle in the desert and live in temporary settlements outside villages and towns (Flood 1975). Even though our results indicated that the roosting distribution of the species was not directly related to the distance to major settlements, this could be explained by the existence of temporary settlements and the overall high abundance of livestock in the whole area. Our results confirm that the spatial distribution of roosting Egyptian vultures depends on the availability of roosting substrates and food (Donázar et al. 1996).

\section{Potential threats}

Considering the significant numbers of roosting Egyptian Vultures in Afar, every potential serious threat may have disastrous effects on the global population and should be considered as a major concern. Ash and Atkins (2009) reported Egyptian Vultures in Ethiopia as frequently found dead, unlike the other vultures. In the present study we did not find any dead Egyptian Vultures. Two Marabous Leptoptilos crumeniferos were found dead on the rubbish dump of Logya, with no cause of mortality identified. The most serious potential threat for the Egyptian Vulture in the region seems to be non-intentional poisoning. Poison baits with strychnine are widely used by veterinary departments in Afar targeting stray dogs (YDA and VA pers. obs.), but this common practice poses a high risk of poisoning or secondary poisoning for the Egyptian Vulture and other scavengers. According to the official procedure poisoning takes place after a special request from the village chief. It is stated that all dead dogs are collected and buried, but this seems not to be the case in Addis Ababa where until April 2013 at least 12000 stray dogs were poisoned, in relation to the potential and growing concern of the risk of rabies to society, and dumped unburied at the city dump (Yilma 2013). This may cause mass poisoning of vultures as they tend to congregate around carcasses. Egyptian Vultures are even more susceptible because they feed on smaller items and may become victims of direct poisoning after consumption of poisoned baits (Carrete et al. 2007). However, more information needs to be collected about the magnitude, scale and timing of these poisoning events in the Afar region in order to address adequate conservation measures.

Another potential threat to the species in the Afar region is electrocution. The Egyptian Vulture is susceptible to electrocution due to its habit of perching and roosting on powerline pylons (Donázar et al. 2002; Angelov et al. 2012). In Africa, large roosting congregations on pylons are reported from Sudan and Ethiopia (Nikolaus 1984; Sigismondi and Politano 1996). Egyptian Vulture roosts are always located near important and predictable food sources (Donázar et al. 1996), thus dangerous powerlines built in these areas may serve as 'deadly traps' for the species (Angelov et al. 2012). Electrocution seems not to be of major concern in the study area as only $4 \%$ of the Egyptian Vultures were observed roosting on dangerous low-voltage types of pylons, whereas the majority of the vultures prefer the safe high-voltage pylons. However, in 2010 local people reported the electrocution of several Egyptian Vultures near the town of Metehara (BSPB and EWNHS unpublished data), which underlines the importance of this potential threat.

\section{Implications for conservation}

Considering the magnitude of the congregation of wintering Egyptian Vultures in the Afar region, precautionary measures need to be undertaken in order to avoid disasterous effects on the global population. All identified sites regularly sheltering significant congregations of the species that are not still under protection should be included in the protected areas network. The area around Bati, Mille, Logya and Serdo should be included in the IBA network because it meets the criteria for an A1 type IBA for globally threatened species through the regular presence of significant numbers of Endangered species (BirdLife International 2014b).

The deteriorating conservation status of the Egyptian Vulture seems primarily linked to incidental mortality from feeding on poisonous baits or deliberately poisoned carcasses to control mammals regarded as pests (Iñigo et al. 2008; Hille and Collar 2011; Virani et al. 2011). Therefore, the widespread practice of mass poisoning of stray dogs in the Afar region, and Ethiopia as a whole (Yilma 2013), should be strictly prohibited and replaced by alternative methods allowing efficient control of the stray dogs numbers and spread of epidemics, e.g. vaccinations and reproduction control by encouraging the castration of male dogs (Kitala et al. 2001; Hemson 2009). Moreover, the sites where poisoned animals could be available for scavengers, e.g. dump sites (Yilma 2013), should be regularly controlled by the local authorities for poisoned animals and dead scavengers.

Relatively low number of Egyptian Vultures were using dangerous types of pylons for roosting. However, consistent losses because of electrocution over large periods may cause declines in the source populations of this Endangered species (Angelov et al. 2012). Therefore, insulation of dangerous powerlines in the sites of congregations of the species in the Afar region or their substitution with safer types of power lines is strongly recommended. New powerlines in the areas important for wintering congregations of Egyptian Vultures should make use of safe pylons or be placed underground.

Acknowledgements - This study was implemented within the frames of the project SSFA/CMSAD/2012/004 financed by the Coordinating Unit of the UNEP/CMS Memorandum of Understanding on the Conservation of Migratory Birds of Prey in Africa and Eurasia Raptors MoU) and the LIFE+ project 'The Return of the Neophron' LIFE10 NAT/BG/000152; http://www. 
LifeNeophron.eu) financed by the European Commission and cofinanced by the AG Leventis Foundation, project financed by the Mohamed bin Zayed Species Conservation Fund, Vulture Conservation Foundation) and donations from Svetoslav Spasov and BSPB members from the UK. Authors are grateful to Nikolay Terziev, Bruktawit Abdu, Ibrahim Hashim, Hassan Djazouli, Eleyeh Abdillahi and Ziad Barkhadle who assisted with field data collection, and to Steffen Oppel, Stoycho Stoychev and Yurii Kornilev for providing helpful comments on preliminary versions of the paper.

\section{References}

Al Bulushi A, Al Harthi S, Al Farsi G, Al Araimi J, Al Humaidi J. 2013. Apparent increases in Egyptian vulture populations in the Sultanate of Oman. Phoenix 29: 15-17.

Angelov I, Hashim I, Oppel S. 2012. Persistent electrocution mortality of Egyptian vultures Neophron percnopterus over 28 years in East Africa. Bird Conservation International 23: 1-6.

Angelov I, Yotzova T, Sarrouf M, McGrady MJ. 2013. Large increase of the Egyptian Vulture Neophron percnopterus population on Masirah island, Oman. Sandgrouse 35: 140-152.

Ash JS. 1981. Bird-ringing results and ringed bird recoveries in Ethiopia. Scopus 5: 85-101.

Ash JS, Atkins J. 2009. Birds of Ethiopia and Eritrea: an atlas of distribution. London: Christopher Helm.

Beauchamp G. 1999. The evolution of common roosting in birds: origin and secondary losses. Behavioral Ecology 10: 675-687.

BirdLife International. 2008. Neophron percnopterus. In: IUCN Red List of Threatened Species. Version 2011.2. Available at http:// www.iucnredlist.org [accessed 13 June 2013].

BirdLife International. 2014a. Species factsheet: Neophron percnopterus. Available at http://www.birdlife.org [accessed 31 January 2014].

BirdLife International. 2014b. BirdLife International data zone: global IBA criteria. Available at http://www.birdlife.org/datazone/ info/ibacritglob [accessed 30 March 2014].

Bontemps S, Defourney P, van Bogaert E, Arino O, Kalogirou V, Perez JR. 2011. GLOBCOVER 2009: products description and validation report. Université catholique de Louvain and European Space Agency. Available at http://due.esrin.esa.int/globcover/ LandCover2009/GLOBCOVER2009_Validation_Report_2.2.pdf [accessed 5 April 2014].

Brown L, Amadon D. 1968. Eagles, hawks and falcons of the world. London: Country Life Books.

BSPB (Bulgarian Society for Protection of Birds). 2013. The return of the Neophron. Available at http://www.lifeneophron.eu/en/ Tagging.html [accessed 5 Aprill 2014].

Buechley E, Sekercioglu C. 2013. Tracking Egyptian Vultures in the Middle East. ARGOS Forum 77: 17.

Carrete M, Grande JM, Tella JL, Sánchez-Zapata JA, Donázar JA, Díaz-Delgado R, Romo A. 2007. Habitat, human pressure, and social behavior: partialling out factors affecting large-scale territory extinction in an endangered vulture. Biological Conservation 136: 143-154.

Ceballos O, Donázar JA. 1990. Roost tree characteristics, food habits and seasonal abundance of roosting Egyptian Vultures in northern Spain. Journal of Raptor Research 24: 19-25.

Ceccolini G, Cenerini A, Aebischer A. 2009. Migration and wintering of released Italian Egyptian Vultures Neophron percnopterus. First results. Avocetta 33: 71-74.

CSA (Central Statistical Agency). 2013. Agricultural sample survey, 2012/13 2005 EC, vol. II: Report on livestock and livestock characteristics (private peasant holdings). Statistical Bulletin 570. Addis Ababa: CSA, Federal Democratic Republic of Ethiopia.

Chhangani AK. 2009. Status of vulture population in Rajasthan, India. Indian Forester 135: 239-251.
Clark W, Schmitt N. 1998. Ageing Egyptian Vultures. Alula 4: 122-127.

Congost J, Muntaner J. 1974. Presencia otoñal e invernal y concentración de Neophron percnopterus en la isla de Menorca. Miscelánea Zoológica 3: 1-11.

Cramp S, Simmons KEL (eds). 1980. The birds of the western Palearctic, vol. 2. Oxford: Oxford University Press.

Donázar JA, Ceballos O, Tella JL. 1996. Communal roosts of Egyptian Vultures (Neophron percnopterus): dynamics and implications for the species conservation. In: Muntaner J, Mayol $\mathrm{J}$ (eds), Biology and conservation of Mediterranean raptors. Madrid: SEO BirdLife. pp 190-201.

Donázar JA, Palacios CJ, Gangoso L, Ceballos O, González MJ, Hiraldo F. 2002. Conservation status and limiting factors in the endangered population of Egyptian Vulture (Neophron percnopterus) in the Canary Islands. Biological Conservation 107: 89-98.

EWNHS (Ethiopian Wildlife and Natural History Society). 1996. Important Bird Areas of Ethiopia. Addis Ababa: EWNHS.

Fergusson-Lees J, Christie D. 2001. Raptors of the world. London: Christopher Helm.

Flood G. 1975. Nomadism and its future: the Afar. RAI News 6(JanuaryFebruary): 5-9.

García-Ripollés C, López-López P, Urios V. 2010. First description of migration and wintering of adult Egyptian Vultures Neophron percnopterus tracked by GPS satellite telemetry. Bird Study 57: 261-265.

Goodman SM, Atta GAM. 1987. The birds of southern Egypt. Gerfaut 77: 3-41.

Hemson G. 2009. EWCP Annual Report - April 2009. Ethiopia: Ethiopian Wolf Conservation Programme.

Hille SM, Collar NJ. 2011. Status assessment of raptors in Cape Verde confirms a major crisis for scavengers. Oryx 45: 217-224.

Ilyin S. 2011. The looming threat of overgrazing: effects and recommendations. Available at http://www.hungercenter.org/ wp-content/uploads/2011/09/Looming-Threat-of-OvergrazingIlyin.pdf [accessed 6 April 2014].

Iñigo A, Barov B, Orhun C, Gallo-Orsi U. 2008. Action plan for the Egyptian Vulture Neophron percnopterus in the European Union. Brussels: BirdLife International and the European Commission.

Janss GFE, Ferrer M. 2001. Avian electrocution mortality in relation to pylon design and adjacent habitat in Spain. Bird Conservation International 11: 3-12.

Kendall CJ, Virani MZ, Hopcraft JGC, Bildstein KL, Rubenstein DI. 2013. African vultures don't follow migratory herds: scavenger habitat use is not mediated by prey abundance. PLOS ONE 9(1): e83470.

Kitala P, McDermott J, Kyule M, Gathuma J, Perry B, Wandeler A. 2001. Dog ecology and demography information to support the planning of rabies control in Machakos District, Kenya. Acta Tropica 78: 217-230.

Levy N, Mendelssohn H. 1989. Egyptian vultures: feeding behavior. Israel Land and Nature 14: 126-131.

Manosa S. 2001. Strategies to identify dangerous electricity pylons for birds. Biodiversity and Conservation 10: 1997-2012.

Margalida A, Boudet J. 2003. Dynamics and temporal variation in age structure at a communal roost of Egyptian Vultures (Neophron percnopterus) in northeastern Spain. Journal of Raptor Research 37: 252-256.

Meinertzhagen R. 1954. Birds of Arabia. Edinburgh: Oliver and Boyd.

Meyburg B-U, Gallardo M, Meyburg C, Dimitrova E. 2004. Migrations and sojourn in Africa of Egyptian Vultures (Neophron percnopterus) tracked by satellite. Journal of Ornithology 145: 273-280.

Mundy PJ, Butchart D, Ledger J, Piper S. 1992. The vultures of Africa. Randburg: Acorn Books.

Nikolaus G. 1984. Large numbers of birds killed by electric power line. Scopus 8: 42. 
Nikolaus G. 2001. Bird exploitation for traditional medicine in Nigeria. Malimbus 23: 45-55.

Ogada DL, Keesing F, Virani MZ. 2012. Dropping dead: causes and consequences of vulture population declines worldwide. Annals of the New York Academy of Sciences 1249: 57-71.

Olendorf RR, Miller AD, Lewhan RN. 1981. Suggested practices for raptor protection on power lines: the state of the art in 1981. Raptor Research Report no. 4. St Paul: Raptor Research Foundation, University of Minnesota.

Porter RF, Suleiman A-S. 2012. The Egyptian Vultrue Neophron percnopterus on Socotra, Yemen: population, ecology, conservation and ethno-ornithology. Sandgrouse 34: 44-62.

Rondeau G, Thiollay JM. 2004. West African vulture decline. Vulture News 51: 13-31.

Salvan J. 1967. Contribution à l'étude des oiseaux de Tchad. L'Oiseau et la revue française d'Ornithologie 37: 225-284.

Sigismondi A, Politano E. 1996. Unusually high concentrations of Egyptian Vulture Neophron percnopterus in a border area of the Dancalia region of Ethiopia. It may be one of the most important wintering areas known. In: Abstracts of the 2nd International Conference on Raptors, Urbino, Italy, 2-5 October 1996. pp 88-89.

Sonneveld BGJS, Pande S, Georgis K, Keyzer M, Seid A, Ali A, Takele A. 2010. Land degradation and overgrazing in the Afar region, Ethiopia: a spatial analysis. In: Zdruli $\mathrm{P}$, Pagliai $\mathrm{M}$, Karpur S, Faz Cano A (eds), Land degradation and desertification: assessment, mitigation and remediation. Netherlands: Springer. pp 97-109.
Stahlecker DW. 1979. Raptor use of nest boxes and platforms on transmission towers. Wildlife Society Bulletin 7(1): 59-62.

Thiollay J-M. 1989. Distribution and ecology of Palearctic birds of prey wintering in West and Central Africa. In: Meyburg B-U, Chancellor RD (eds), Raptors in the modern world. Berlin: World Working Group on Birds of Prey. pp 95-107.

Thiollay J-M. 2006. Severe decline of large birds in the northern Sahel of West Africa: a long-term assessment. Bird Conservation International 16: 353-365.

Thiollay J-M. 2007. Raptor population decline in West Africa. Ostrich 78: 404-413.

UN-EUE (United Nations Emergencies Unit for Ethiopia). 2002. Afar: insecurity and delayed rains threaten livestock and people. Geneva: United Nations.

Virani M Z, Kendall C, Njoroge P, Thomsett S. 2011. Major declines in the abundance of vultures and other scavenging raptors in and around the Masai Mara ecosystem, Kenya. Biological Conservation 144: 746-752.

Wacher T, Newby J, Houdou I, Harouna A, Rabeil T. 2013. Vulture observations in the Sahelian zondes of Chad and Niger. Bulletin of the African Bird Club 20: 186-199.

Wilson RT. 1982. Environmental changes in western Darfur, Sudan, over a half century and their effects on selected bird species. Malimbus 4: 15-26.

Yilma D Abebe 2013. Mass dog poisoning operation in Addis Ababa can have severe repercussions on vulture populations. Vulture News 64: 74-76. 